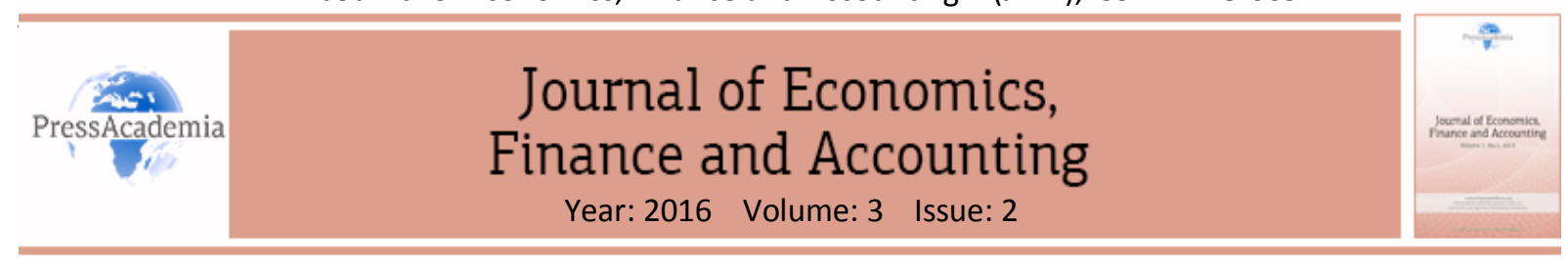

\title{
THE JORDANIAN STOCK EXCHANGE: CAN IT DELIVER WHAT IS EXPECTED?
}

\section{DOI: 10.17261/Pressacademia.2016219774}

\author{
Ghassan Omet ${ }^{1}$ \\ ${ }^{1}$ University of Jordan. gomet@ju.edu.jo
}

\begin{abstract}
Financial development in Jordan should be underestimated for two main reasons. First, the total assets of licensed banks constitute about 180 percent of Gross Domestic Product (GDP). Second, the country boasts one of the oldest stock markets in the region. The Amman Securities Exchange (ASE) was established in 1978 and its current capitalization is equivalent to about 75 percent of GDP. Given Jordan's socio-economic challenges, and the fact that successive governments have been suffering from large and consistent budget deficits, it does not make economic sense that the ASE has no active secondary bonds market. The issued government securities are sold to all licensed banks. This observation is unfortunate. Avoiding the concentration of financial intermediation in banks makes sense. In addition, whilst a well-developed bond market allows banks to transfer their risk (securitization), such a market makes the conduct of monetary policy more effective and contributes to budgetary discipline by exposing the government to financial discipline. This paper argues for the need for developing a government securities market in Jordan. In addition, the paper examines the already listed shares in terms of their liquidity cost. Based on the empirical results, it is reported that listed shares suffer from high liquidity cost. This finding and its implications are useful in recommending what must be done to develop an active bonds market.
\end{abstract}

Keywords: Amman Securities Exchange, bid-ask spread, Government Securities Market. JEL Classification: G10, G12, G15.

\section{INTRODUCTION}

The growth experience of nations has kept the best economics minds busy for centuries. Indeed, this interest has led to the development of several theories. These include Solow's (1956) neoclassical model, endogenous growth theories (Romer, 1986 and Lucas (1988), cumulative causation theory (Myrdal, 1957 and Kaldor, 1970), and the New Economic Geography School (Krugman, 1991). Moreover, other approaches model the importance of institutions (North, 1990), and political science (Brunetti, 1997) in the growth process.

As one might expect, the theoretical effort in economic growth has resulted in too many empirical papers to review in any single output. However, it can be stated that this literature, using different econometric techniques, considers the impact of many factors on real economic growth. Some of these variables are innovation and research and development, foreign direct investment, openness to trade, financial development, and others.

The economic role of banks and stock markets has had its fair share in the literature. Even international organizations have expressed interest. The World Economic Forum defines financial development as the "factors, policies, and institutions that lead to effective financial intermediation and markets, as well as deep and broad access to capital and financial services". Also, the World Bank defines the concept of financial development as improvements in the quality of five financial functions (production of information about possible investments, monitoring individuals and firms and exerting governance, facilitating trading, diversification, and management of risk, mobilizing and pooling savings, and the easing the exchange of goods, services, and financial instruments).

Given the importance of financial development, one can understand why "a large body of economic literature supports the premise that, in addition to many other important factors, the performance and long-term economic growth and welfare of a country are related to its degree of financial development" (World Economic 
Forum). Relative to this conclusion, the empirical literature which examines the impact of financial development on growth is extremely large. In actual fact, a number of papers whose objective is to review this literature only, have been published and these include Ang (2008), Beck (2012), and Barajas (2013).

On average, given the positive impact of financial development on growth, the literature also examines the impact of financial development on poverty and inequality and the determinants of financial development itself. Some of the more recent papers that examine these issues are published by Ben Naceur and Zhang (2016) and Almarzoqi et al. (2015). As far as the Middle East and North Africa (MENA) region is concerned, the issues of the impact of financial development on growth and the determinants of financial development are examined by Hamadi and Bassil (2015) and Cherif and Dreger (2014) respectively.

As a part of most financial systems, the literature raises two theoretical arguments for the economic importance of stock markets. First, due to the fact that most economically profitable projects require investments for a long time period, liquid stock markets allow investors to commit their funds in such projects because they can sell the issued and subscribed securities whenever they want on the secondary market. This argument, which is commonly referred to as the level effect, is due to Levine (1991). Second, liquid markets with a diverse set of financial securities provide investors with diversification benefits in terms of expected return and expected risk levels. This benefit enables investors to allocate some of their funds in high-risk with high-return projects. This shift in the capital flows promotes efficiency with which capital is allocated. Again, this argument, referred to as the efficiency effect, is due to Greenwood and Jovanovic (1990).

Within the context of financial development in general, and stock markets in particular, one cannot underestimate the importance of developing government (and corporate) securities market. For example, the fact that infrastructure projects require long-term commitments of capital, the presence of liquid bond markets (and stocks) eases this problem by providing an asset (bonds) to savers which they can easily sell whenever they want. The establishment of efficient government bond market involves other benefits too (USAID, 2010). First, if a nation borrows in foreign currency, depreciation of the local currency would worsen the government's balance sheet and increase the debt burden. Second, avoiding the concentration of financial intermediation in banks makes economic sense. Also, a well-developed bond market allows banks to transfer their risk through securitization. Third, such a market enhances economic stability by enabling the government to pursue expansionary fiscal policy in recession times. Finally, government bonds market provides economies with a risk-free benchmark, makes the conduct of monetary policy more effective, improves the intermediation of savings, and contributes to budgetary discipline by exposing the government to financial discipline.

Relative to the issue of developing government securities market and its benefits, it is interesting to note that successive Jordanian governments have been dependent on external grants and local and foreign borrowing for funding their deficits. Indeed, since 1970, the budget has been consistently in deficit. For example, excluding aid, this deficit was equal to 22.1 percent of GDP (1970), 28.6 percent (1980), 9.9 percent (2000), 7.7 percent (2010), and 7.2 percent (2014). It is also interesting to note that Jordanian governments have never really tried to develop a vibrant local bonds market. In actual fact, the issued local bonds by the central government and public entities are sold to local banks only and do not trade on the secondary market. They are "allocated" to each bank according to the ratio of its assets to the total assets of all banks. Currently, these securities account for about 25 percent of the assets of all Jordanian banks. This observation is also surprising knowing that the Amman Securities Exchange (ASE) is one of the oldest markets in the region. The ASE was established in 1978.

This paper makes a case for the need to establish a government securities market in Jordan. In addition, the paper examines the already listed shares in terms of their liquidity cost. This analysis, it is argued, is useful because of the implications of the results in establishing an efficient government securities market in Jordan.

The rest of the paper is organized as follows. To argue for the desperate need for developing a government securities market in Jordan, we provide, in section 2, some relevant information about the Jordanian economy in general, and public finance in particular. In section 3, we examine the ASE in terms of the liquidity cost of all its listed stocks. Based on these results, we draw conclusions and implications for developing a government securities market. Finally, we summarize and conclude the paper in section 4 . 


\section{THE JORDANIAN ECONOMY AND PUBLIC FINANCE}

Jordan is classified by the World Bank as a "lower middle income country". GDP per capita is around $\$ 5,500$. Based on purchasing power parity (international dollars), per capita GDP is about $\$ 12,100$. The Jordanian economy has been wrestling with a number of socio-economic challenges and characteristics. These challenges and characteristics are briefly outlined below.

First, in 2010 and 2015, the overall unemployment rates were equal to 11.0 percent, and 13.6 percent respectively. In terms of gender, age and education, the unemployment problem is even more serious. Among females, 15-19 years old, 20-24 years old, and those with an undergraduate (or higher) degree, unemployment rates are equal to 23.0 percent, 39.7 percent, 32.1 percent, and 17.6 percent respectively.

Second, the labour force participation rate (among the 15-64 years old) is equal to 44 percent. This low rate is primarily due to the extremely low female participation rate (17 percent). However, it is useful to realize that this rate was equal to 9.8 percent in 1990 and 14.1 percent in 2012. In other words, unless the economy creates more employment opportunities than ever before, the rising female participation rate is going to make the overall and male unemployment problems even more challenging to solve.

Third, set at JD813 (\$1160) annual per capita income level, the 2010 official figures indicate that the poverty rate is equal to $14.4 \%$. This rate hides the fact that 22.5 percent of households are vulnerable to poverty because their income lies between 1 and 1.5 times the poverty line.

Fourth, the economy receives large amounts of capital inflows in the form of aid and remittances. Relative to GDP, these inflows in 2014 constituted about 4.9 percent and 9.4 percent respectively (Figure 1)

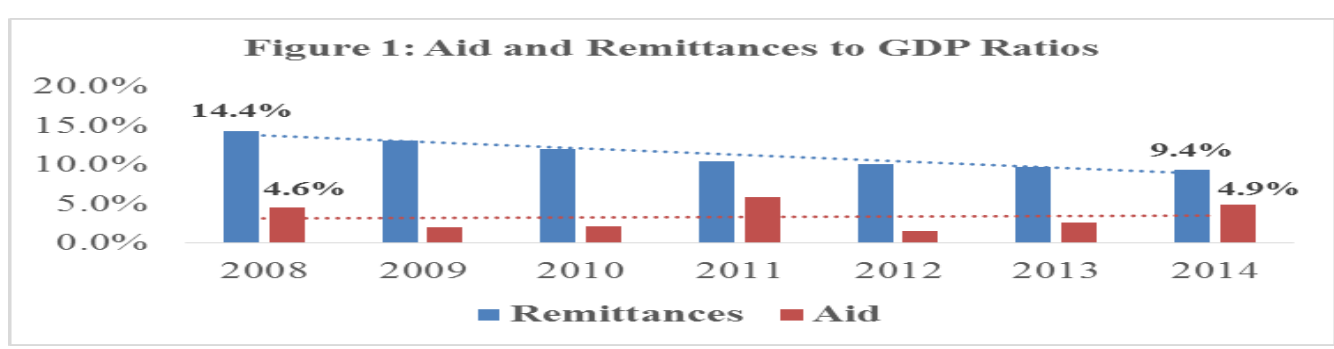

Fifth, governments suffer from budget deficits (Figure 2).

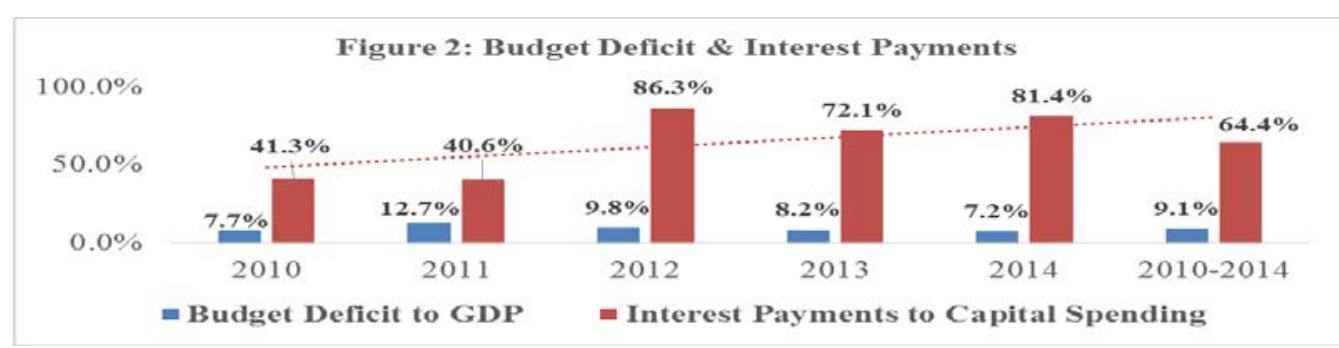

Sixth, the tax effort remains relatively low (Figure 3)

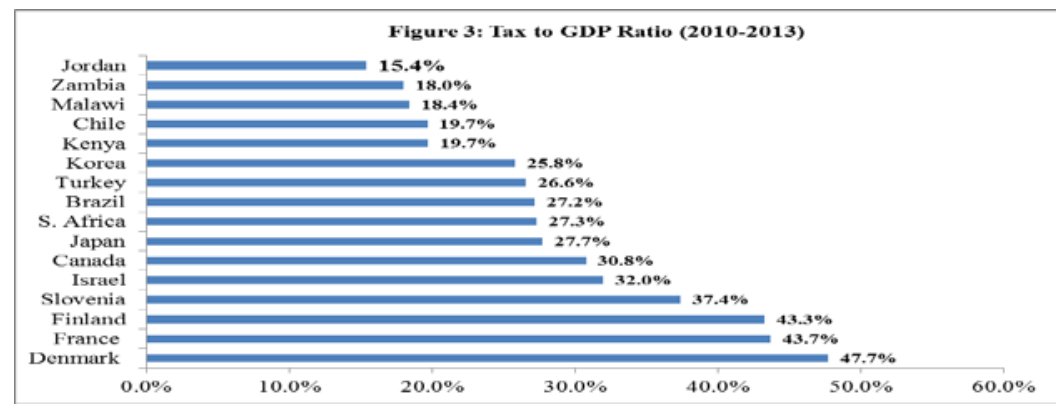


Seventh, within the context of the low tax effort, it is informative to note 68 percent of total tax revenue emanates from sales tax, and this is much higher than the OECD average (40 percent). Also, individuals who earn wages and private sector businesses (non-corporate) contribute very little towards total tax revenue (Figure 4).

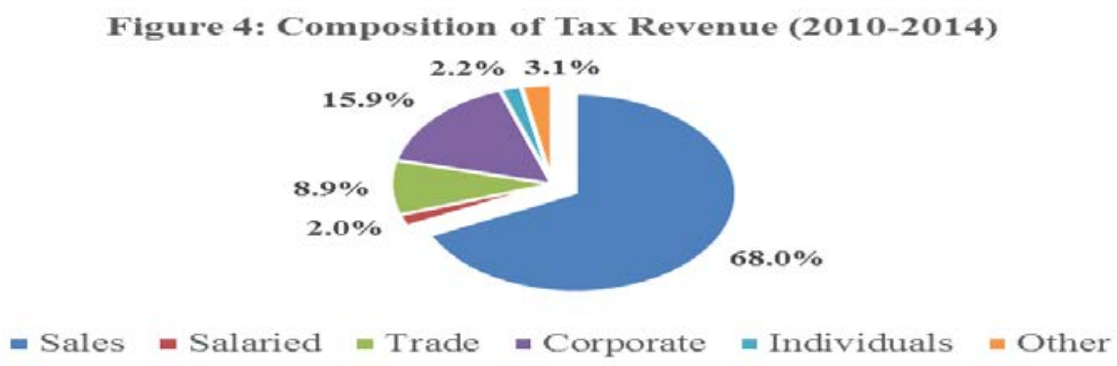

Finally, the economy suffers from consistent trade deficit. During the period 2010-2014, this deficit to GDP ratio was around the 42 percent mark (Figure 5) and this is comparable to the 1975-1980 ratio (51 percent).

\begin{tabular}{|c|c|c|c|c|c|c|}
\hline \multicolumn{7}{|c|}{ Figure 5: Trade Deficit to GDP Ratio } \\
\hline$-20.0 \%$ & 2010 & 2011 & 2012 & 2013 & 2014 & $2010-2014$ \\
\hline$-40.0 \%$ & $\sim$ & & & & & \\
\hline$-60.0 \%$ & $-36.4 \%$ & $-42.2 \%$ & $-45.5 \%$ & $-44.9 \%$ & $-43.2 \%$ & $-42.4 \%$ \\
\hline
\end{tabular}

Underlying the above-mentioned socio-economic challenges and characteristics of the Jordanian economy, it is unfortunate to realize that total government spending to GDP ratio has fallen from an annual mean value of 43 percent (1970-1980) to 35.8 percent (2005-2010) and to 30.9 percent in 2014 (Figure 6). More importantly, this decrease was largely due to its' capital component. In actual fact, capital spending has fallen from 15 percent (1970-1980) to 8.4 percent (1990-2000), 7.5 percent (2000-2005), and to 4.5 percent in 2014.

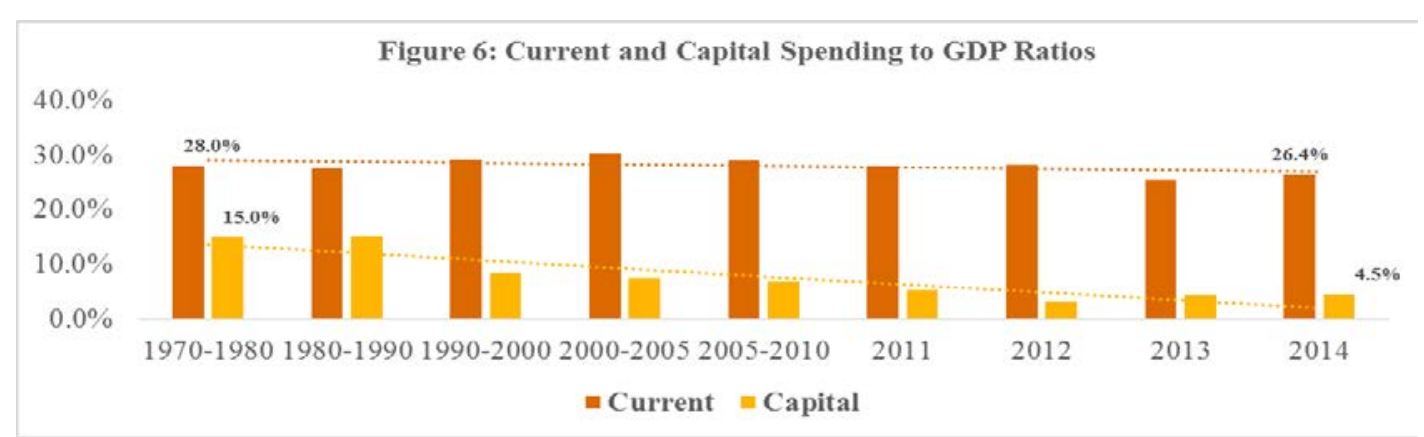

Against the decrease in both total spending and capital spending, and during the period 2004-2015, the population of Jordan (Jordanians) has increased by 3.1 percent. Whilst this ratio is relatively high, it is still much lower than the increase in the non-Jordanian (largely refugees) population (18 percent). In other words, the decrease in capital spending must have had serious implications to the infrastructure deficit facing the economy.

To appreciate the implications of the decrease in capital investments, one only needs to look at Jordan's international rank in terms of: 
1- Competitiveness Index: With a score of 4.25, Jordan ranks 64th out of 140 countries in the overall competitiveness index (World Bank). On the dimension of macroeconomic stability Jordan ranks $131^{\text {st }}$ (Figure 7).

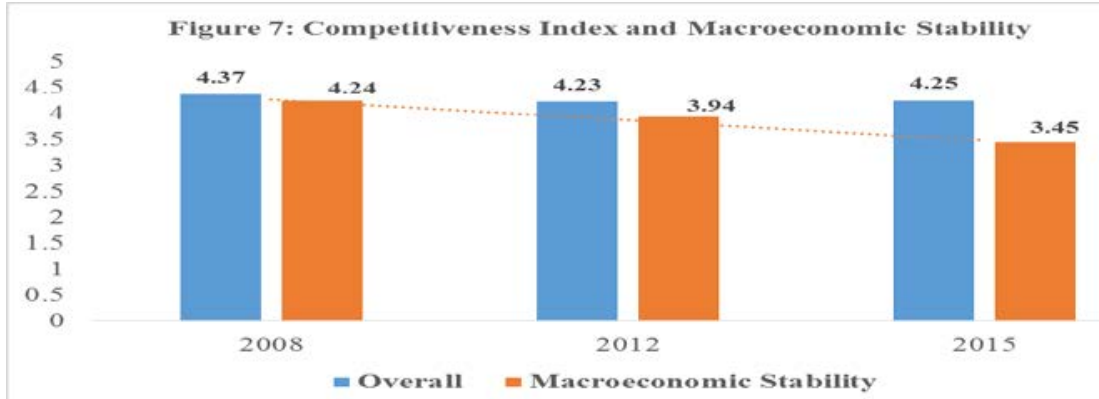

2- Logistic Performance Index: The World Bank's Logistic Performance Index, and its' transport-related infrastructure dimension reflects the poor status of Jordan.

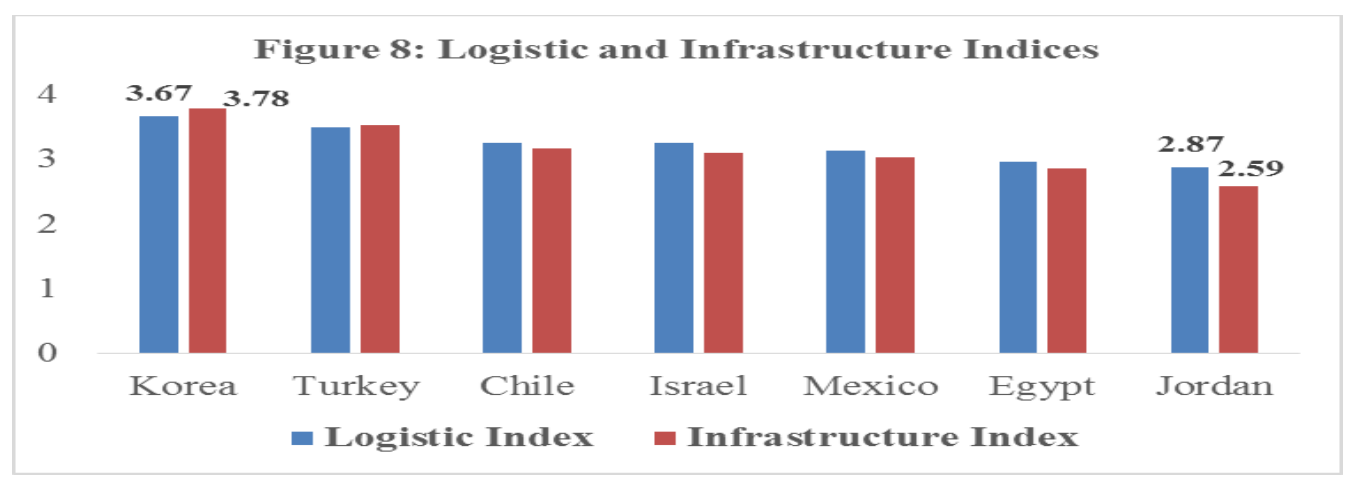

3- Governance Indicators: The Worldwide Governance Indicators in terms of government effectiveness and regulatory quality are poor.
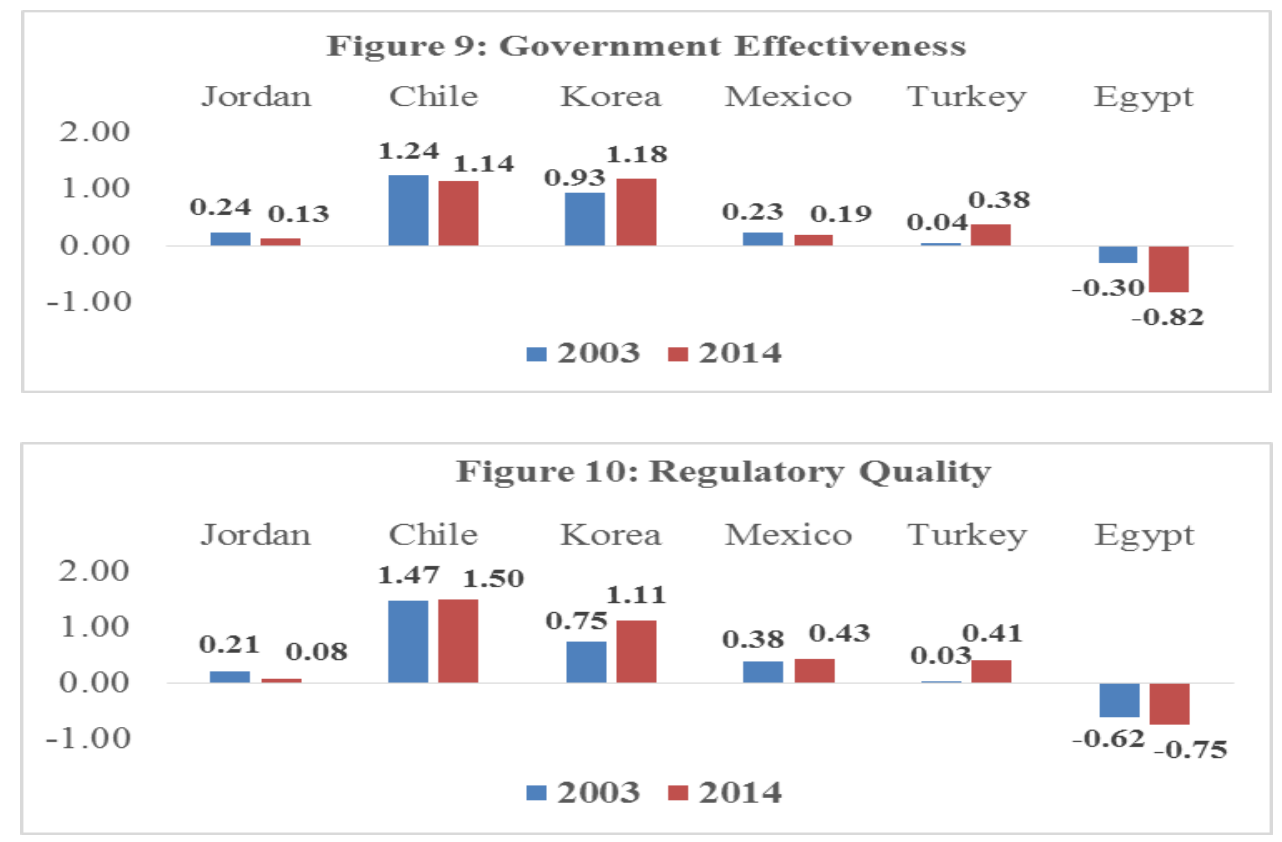

4- Energy Architecture: The World Economic Forum's 2014 Global Energy Architecture Performance Index reflects the relatively poor Jordanian circumstances. 


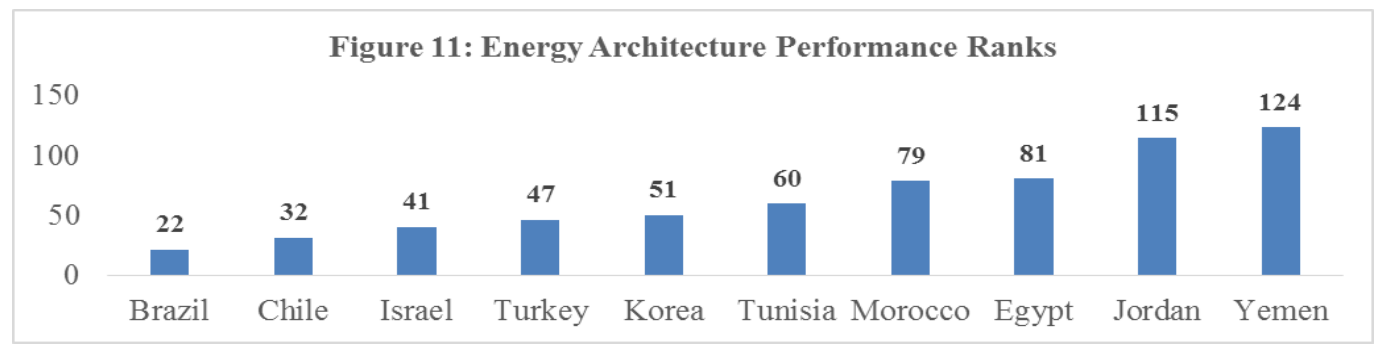

The impact of the prevailing characteristics of the Jordanian economy and its current realities and challenges, observations about government fiscal policy, and the above-mentioned seven questions could not have been positive. Cumulatively, they have made successive governments look weak, inefficient, and unpopular. This is reflected in the survey results of the average Jordanian in 1999-2004 and 2010-1014 (World Values Survey Association).

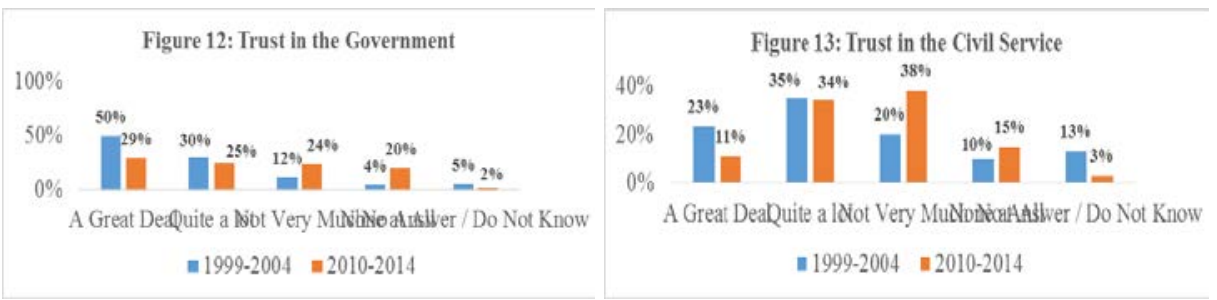

Based on the above brief outline of the socio-economic challenges facing Jordan, characteristics of the economy, and few observations about total government spending, we can make the following statements.

First, the national economy receives sizeable amounts of capital inflows in the form of aid and remittances and suffers from consistent trade deficit. Second, the central government suffers from consistent budget deficit and the tax to GDP ratio remains relatively low. Third, economic growth should be a worrying factor to policymakers because of the problems posed by the consistently high unemployment rates, rapidly expanding labor force, increasing female participation rate, and the existing poverty levels.

Finally, it is ironing that successive Jordanian governments suffer from consistent budget deficits and macroeconomic instability, rely on low tax effort in financing their spending, and recently, have issuing various government securities (treasury bills, treasury bonds, development bonds, and various public institutions bonds) in growing proportions. This irony stems from the fact that the Jordanian state, it can be argued, must not only increase the tax revenue from the current 14 percent of GDP, but also must develop the government securities market in its secondary aspect. Together, they should enable the government meet its long-term capital spending requirement but also promote greater levels of macroeconomic stability.

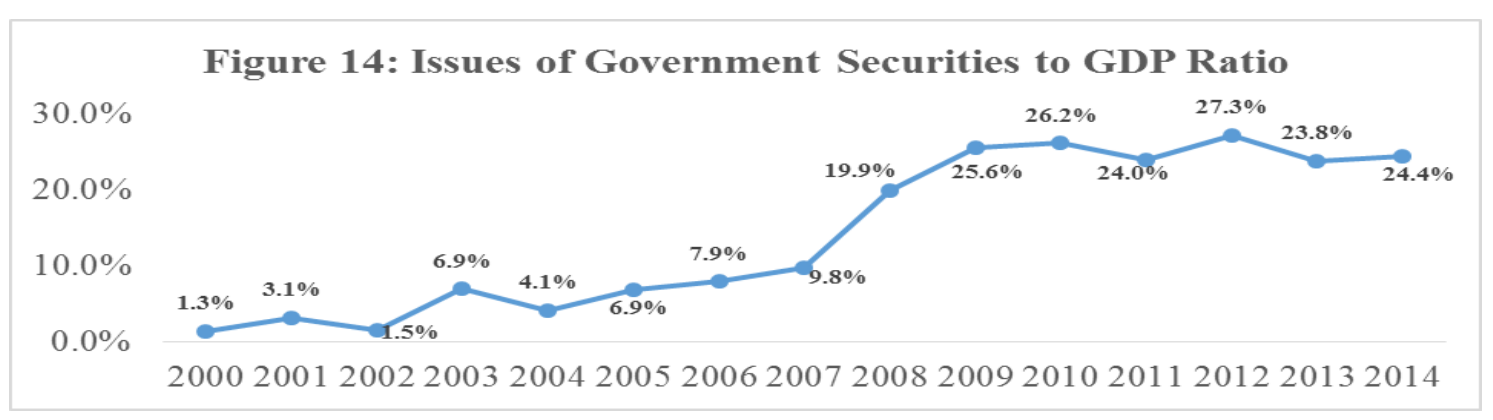

\section{THE JORDANIAN STOCK EXCHANGE: THE LIQUIDITY ISSUE}

The ASE which was established back in 1978 is one of the oldest markets in the region. Naturally, during its first few years in operation, the market reflected modest figures. For example in 1978, the market had a total of 66 listed firms. By the end of 2015, this number has increased to 228 firms. Indeed, some of these firms are the largest in the country in terms of assets and number of employees. However, it is also useful to note that the 
market has suffered from some extreme volatility in prices. This volatility is reflected in the market's capitalization to GDP ratio. For example, whilst this ratio was equal to 36 percent in 1978, 70 percent in 1996, 58 percent in 2000, and 299 percent in 2005, the ratio collapsed to 197 percent in 2007, 87 percent in 2012, and to 66 percent by the end of 2015 .

Irrespective of what the reasons behind the collapse in the ASE's capitalization to GDP ratio are, this observation is not encouraging if the Amman Securities Commission, together with the Ministry of Finance wants to establish an active bonds market. Indeed, one way of looking at this issue is to examine the liquidity cost that prevails in the shares of all listed firms.

The ASE publishes detailed daily reports. These reports include several measures including closing prices, trading volume, number of transactions, closing best bid prices and closing best ask prices, and others. These reports constitute the source for all the relevant data that enter our analysis.

Due to the non-availability of within-day data (transaction-to-transaction data), we use the difference between the closing ask and bid prices as the relevant measure for liquidity cost. Indeed, the fact that these closing best bid and best ask are random in terms of their arrival times at the market, the difference can be a good measure of liquidity cost. In other words, our relevant measure of liquidity cost is represented by the following expression;

$$
\text { Spread }=[(\text { Best Ask }- \text { Best Bid }) /(\text { Best Ask }+ \text { Best Bid / 2) }] * 100
$$

The above equation was used to estimate the liquidity cost for all listed firms during the period 2002-2014. Before we report the results, it is useful to note that stock prices are not allowed to change during any trading day by more than 5 percent. This law is important in estimating liquidity cost. If in any day, the closing bid or ask price might cause a daily change in price by more than the 5 percent, these ask and bid prices are deleted and not included in the calculation.

In Figure 15, we report the overall mean liquidity costs. A look at the reported spread values, one cannot but conclude that liquidity cost that prevails in the Jordanian capital market is relatively high. Indeed, even the mean spread in 2004 (1.5 percent) is much greater than the 0.018 percent and the 0.037 percent that exist in the NYSE and NASDAQ markets respectively (Jiang et al., 2011). In addition, the 1.5 percent cost is much higher than those reported by Gagnon and Gimet (2013) for European markets (0.331 percent) and Canada (0.213 percent). Finally, liquidity cost in the Chinese market is equal to 0.217 percent (Ding et al., 2013).

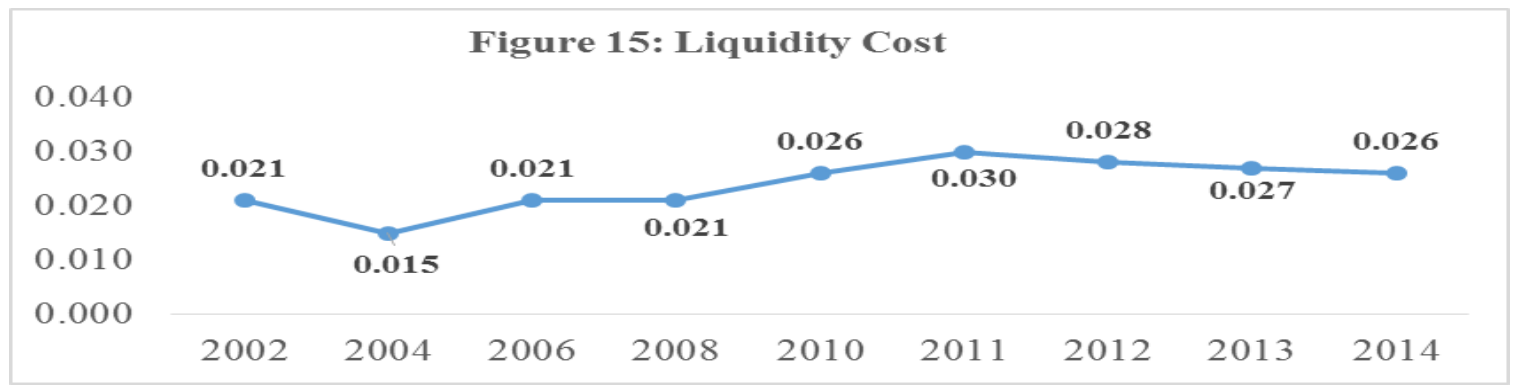

As far as government bond markets are concerned, a recent paper (Goyenko et al., 2011) examined how liquidity cost varies across different maturities. The empirical results indicate that spreads increase in recessions across all maturities. On average, liquidity cost is equal to 0.149 percent during recessions and 0.101 during non-recession periods. Also, for treasury bills (short-term bonds), liquidity cost is equal to 0.049 percent in recessions and 0.002 percent in non-recession periods.

The comparatively high liquidity cost in the ASE is due to several reasons. However, one cannot ignore the role of market-makers. The fact that the trading mechanism on the ASE does not have market-making (brokeredmarket), the relatively high liquidity cost cannot be reduced unless this institution (market-making) is introduced. Indeed, the available evidence clearly points out the fact that markets which introduced marketmakers witnessed some significant decreases in their liquidity costs (see, for example, Jain, 2003). 
In addition to the above results, we estimated an OLS regression that looked as follows:

$$
\text { Spread }_{i, t}=\alpha_{0}+\alpha_{1} \ln \left(V O L_{i, t}\right)+\alpha_{2} \ln \left(P R I C E_{i, t}\right)+\alpha_{3}\left(R I S K_{i, t}\right)+\alpha_{4} \ln \left(D U M_{i}\right)+\varepsilon_{i, t}
$$

where spread is as defined above, VOL is the natural logarithm of trading volume, PRICE stands for the natural logarithm of closing price, RISK is measured by the difference between the highest and lowest price (during days) divided by the closing price, and DUM is a dummy variable which is equal to 0 if the firm is listed on the first market and 1 if listed on the second market.

The estimated results are as one might expect. In all years, the signs of the coefficients are fairly similar in terms of sign and significance.

Table 1: 2014 Regression Results

\begin{tabular}{|l|c|c|}
\hline Variable & Coefficient & t-Statistics \\
\hline VOL & -0.005 & $6.325^{*}$ \\
\hline PRICE & -0.007 & $-6.614^{*}$ \\
\hline RISK & 0.250 & $43.994^{*}$ \\
\hline DUM & 0.018 & $7.749^{*}$ \\
\hline Adj. $R^{2}$ & 0.350 & \\
\hline * Significant at the 99 percent level. & \\
\hline
\end{tabular}

For illustrative purposes, we report in Table 2 the 2014 results. The coefficient of trading volume (VOL) is negative and significant. In other words, the more the stock is traded the lower its liquidity cost. The coefficient of stock price (PRICE) is negative. Again, this is expected given the fact that the minimum tick which is allowed in the ASE is 1 pence (100 pence equivalent to 1 Dinar). The risk factor (RISK) enters positive in its impact on liquidity cost. In other words, when volatility is low, one should expect narrower bid-ask spreads. Finally, the coefficient of the dummy variable is positive. Again, this result is expected as newly listed firms which tend to be less well-known are expected to have wider bid-ask spreads.

\section{SUMMARY AND CONCLUSIONS}

Given Jordan's socio-economic challenges, the national economy must achieve sustainable and strong economic performance. This objective can be achieved, if and only if, successive Jordanian governments can adopt meet the country's growing requirements in terms of both physical and social infrastructure investments. Based on these arguments and the fact that successive governments suffer from consistent budget deficits, it is imperative to develop well-functioning and liquid government securities market. In addition, and to complement this effort, a new tax policy that would increase the tax effort must be adopted.

The establishment of a liquid secondary market for government securities is a complex task. A number of measures must be in place for its development. These are listed below.

1- The government must a credible issuer of securities (debt).

2- Macroeconomic conditions must have some degree of stability.

3- The government must be prepared to pay the prevailing market interest rates.

4- The capital market must have the necessarily required technical and regulatory frameworks.

Based on the time period 2002-2014, the results indicate that liquidity cost on the Jordanian capital market is relatively high. The government must be aware of this cost and any steps to activate the secondary market for government securities must take this observation into consideration. In addition, market-makers must be introduced in order to maintain this cost at manageable proportions. 


\section{REFERENCES}

Almarzoqi, R., S. Ben Naceur and A. Kotak (2015). What matters for financial development and stability?, IMF Working Paper No. $15 / 173$.

Ang, J. (2008). A survey of recent developments in the literature of finance and growth. Journal of Economic Surveys 22, 536-576.

Barajas, A., R. Chami, and S. Yousef (2013). The finance and growth nexus re-examined: Do all countries benefit equally?, IMF Working Paper No. 13/130.

Ben Naceur, S. and R. Zhang (2016). Financial development, inequality and poverty: Some international evidence. IMF Working Paper No. 16.32 .

Brunetti A., (1997). Political variables in cross-country growth analysis. Journal of Economic Surveys 11, 163-190.

Cherif, M. and C. Dreger (2014). Institutional determinants of financial development in MENA countries. German Institute for Economic Research, Discussion paper No. 1422.

Ding, M., B. Nilsson and S. Suardi (2013). Foreign institutional investors and stock market liquidity in China: State ownership, trading activity and information asymmetry. Working Paper No. 14, The Knut Wicksell Centre for Financial Studies, Lund University.

Gagnon, M. and C. Gimet (2013). The impacts of standard monetary and budgetary policies on liquidity and financial markets: International evidence from the credit freeze crisis. Journal of Banking and Finance 37, 4599-4614.

Goyenko, R., A. Subrahmanyam and A. Ukhov (2011). The term structure of bond market liquidity and its implications for expected returns. Journal of Financial and Quantitative Analysis 46, 111-139.

Greenwood, J. and Jovanovic, B. (1990). Financial development, growth, and the distribution of income. Journal of Political Economy 98 , 1076-1107.

Hamadi, H. and C. Bassil (2015). Financial development and economic growth in the MENA region. Comparative Economic Studies 57, 598622.

Jain, P. (2003). Institutional design and liquidity of stock exchanges around the world. Working Paper, Indiana University.

Jiang, C., J. Kim and R. Wood (2011). A comparison of volatility and bid-ask spread for NASDAQ and NYSE after decimalization. Applied Economics 43, 1227-1239.

Kaldor N. (1970). The case for regional policies. Scottish Journal of Political Economy 17, 337-348.

Krugman P. (1991). Increasing returns and economic geography. Journal of Political Economy 99, 183-99.

Levine, R. (1991). Stock markets, growth, and tax policy. Journal of Finance, 46, 1445-1465.

Lucas R. (1988). On the mechanics of economic development. Journal of Monetary Economics 22, 3- 42.

Myrdal G. (1957). Economic theory and underdeveloped regions, Hutchinson Publications.

North D. (1990). Institutions, institutional change and economic performance. Cambridge: Cambridge University Press

Romer P. (1986). Increasing returns and long run growth. Journal of Political Economy 94, 1002-1037.

Solow, R. (1956). A contribution to the theory of economic growth. The Quarterly Journal of Economics 70, 65-94.

USAID (2010). Developing government bond markets. FS Series No, 12. 